\title{
An overview of popular website platforms and mobile apps for language learning
}

\author{
Popularne platformy internetowe \\ i aplikacje mobilne do nauki języków obcych \\ Anna BĄCZKOWSKA ${ }^{1}$ \\ University of Gdańsk
}

\begin{abstract}
This paper aims at providing a survey of the most popular online educational platforms and mobile apps for language learning. It gives an overview of the development and current trends in what is generally labelled computer-assisted language learning (CALL) with reference to select pedagogical theories; in particular, those embedded in the theoretical framework of broadly defined constructivism, as well as select learning processes, including self-regulation, self-directed learning, personal knowledge management and the concept of learner autonomy. Following this theoretical backdrop, the analysis of 30 educational platforms for language learning is presented, which were evaluated against several criteria, such as accessibility, revised Bloom et al.'s taxonomy of learning outcomes, language levels, typology of exercises, etc.

Keywords: language learning, website platforms, mobile apps for language learning, constructivism, CALL

\section{Streszczenie}

Celem artykułu jest dokonanie przeglądu najpopularniejszych platform edukacyjnych i aplikacji mobilnych do nauki języków obcych. Na wstępie zarysowany jest rozwój tzw. CALL (ComputerAssisted Language Learning), czyli nauki języków wspomaganej komputerowo, w odniesieniu do wybranych teorii pedagogicznych, w szczególności teorii z zakresu szeroko rozumianego konstruktywizmu. Ponadto, objaśnione są wybrane procesy uczenia się, takie jak samoregulacja,
\end{abstract}

1 https://orcid.org/0000-0002-0147-2718

Uniwersytet Gdański/University of Gdańsk

anna.baczkowska@ug.edu.pl 
uczenie się bez nadzoru, zarządzanie własną wiedzą oraz związane z nim pojęcie autonomii ucznia. W drugiej części artykułu przedstawiona jest analiza 30 platform/aplikacji edukacyjnych do nauki języków, którą przeprowadzono według kilku kryteriów, takich jak dostępność, efekty uczenia się według zrewidowanej taksonomii Blooma i in., poziomy językowe, typologia ćwiczeń itp.

Słowa kluczowe: uczenie się języków, platformy internetowe, aplikacje mobilne do nauki języków, konstruktywizm, uczenie się języków wspomagane komputerowo

\section{Computer-Assisted Language Learning}

Levy (1997, p. 1) defined CALL in very broad terms as "the search for and study of applications of the computer in language learning and teaching". With time, the definition of CALL has extended to encompass not only what was traditionally associated with CALL, i.e., a classroom-based teaching/learning, but also devices used predominantly outside of the classroom walls. This redefined concept was termed integrated CALL by Bax (2003, p. 21), which is a broader term than what Warschauer (1996) dubbed integrative CALL.

What was once called Computer Assisted Language Learning (CALL; Ahmad et al., 1985) has seen rapid development and transformation over the last thirty years. The traditional CALL approach distinguished the so-called three phases (Warschauer, 1996) - behaviouristic, communicative and integrative. They reflected the earlier waves of interests and developments in linguistics, e.g., Skinner's behaviourist theory of learning or the reaction to it in the form of cognitivism proposed by Chomsky, as well as paralleled technological developments, such as the birth of the Internet. Thus, rote learning predicated on the drill and practice mode that predominated the beginnings of CALL (the '70s and '80s), with its focus on accuracy, was embodied by the behaviouristic phase. This was next replaced by exercises endorsing effective communication and fluency (the '80s), which was promoted in the communicative phase. With the '90s, CALL started to incorporate the first multimedia (e.g., CD-ROMs) and next the Internet for the use of language learning which characterised the integrative phase. With the technological development of the Internet, mobile phones and artificial intelligence, CALL has undergone a number of transformations into, inter alia, WALL (Web-Assisted Language Learning; Gitsaki and Taylor, 1999; Ruipérez, 2002), MALL (Mobile-Assisted Language Learning, Stockwell,

${ }^{2}$ In a later publication, Warschauer and Kern (2000) changed the name behaviouristic into structural. 
2012a), and ICALL (Intelligent Computer-Assisted Language Learning, Schulze and Heift, 2013). Internet-based language learning, in turn, has been dubbed inter alia Online Language Learning, OLL for short (Blake, 2011), WebEnhanced Language Learning, i.e., WELL (Allodi et al., 2014), Web-Based Language Learning (WBLL, Heift, 2005), or Technology-Enhanced Learning Environments (TELE, Mahlow, 2010). The object of interaction of the human has changed accordingly, from stationary computers, through portable ones (laptops, palmtops, tablets), to mobile phones (smartphones), and from desktop software to mobile apps and online interactive web platforms. Despite the variety of names that conceptualise language learning with the aid of computers and the Internet, the term CALL is suggested to be used as a generic term, which spans a number of its forms (Stockwell, 2012b, p. 10), and thus it will be deployed in this overarching sense in this paper.

Following these redefinitions, the forms of communication between humans and the computer have changed. What used to be called ComputerMediated Communication (Herring, 1996) has lost ground to what now tends to be replaced by IMC standing for Internet-Mediated Communication (Yus, 2011) or TMC to indicate Technology-Mediated Communication (Placencia and Eslami, 2020). The revolution we witness in technology encroaches on education in general, and language learning has not stood aside from this movement; hence, nowadays, we may be talking about Technology-Mediated Language Learning (Chapellle, 2019, TMLL), or Technology-Assisted Language Learning (TALL). Whilst in the early phases of CALL, the learner interacted only with computers, in the integrative phase, interaction started to also involve other learners through networking (social media), which often leads to the creation of communities of practice (Lave and Wenger, 1991), consisting of people who share their knowledge and the same interest and passion for learning languages with the use of computers and/or mobile phones.

Despite some caution, or at best moderate opinions expressed about the efficacy of technology-enhanced language learning by some scholars, both regarding CALL (e.g., Golonka et al., 2014) and MALL (e.g., Garcia Botero et al., 2021), there are also positive claims about using technology in language learning. One asset is seen in the fact that TELL is a tool promoting personal knowledge management (PKM; Frand and Hixon, 1999; Cigognini et al., 2011) associated with the ability of a learner to, inter alia, analyse, evaluate, organise, create and share information. The other merit recurring in literature is seen in reinforcing self-directed learning (SDL; Holec, 1980; Garrison, 1997; Garrison and Anderson, 2003; Lai et al., 2016; Garcia Botero et al., 2019), 
whereby "individuals take the initiative, with or without the help of others, in diagnosing their learning needs, formulating learning goals, identifying human and material resources for learning, choosing and implementing appropriate learning strategies, and evaluating learning outcomes"3 (Knowles, 1975, p. 18). PKM and SDL alike are types of learning that are predominantly independent of the teacher, and are believed to endorse learner autonomy ${ }^{4}$ (Warschauer et al., 1996; Gitsaki and Taylor, 1999, p. 143; Blin, 2004; Egbert et al., 2007, p. 4; Vinther, 2012, p. 161; Reinders and Hubbard, 2013; Liaw and English, 2017) and empower self-regulation (Vovides et al., 2007; Lai and Gu, 2011; Su et al., 2018; Zheng et al., 2018; Li et al., 2020). Self-regulation is defined by Zimmerman (2002, p. 65) as follows: "Selfregulation refers to self-generated thoughts, feelings, and behaviours that are oriented to attaining goals". It is "a self-directed process by which learners transform their mental abilities into academic skills", and this transformation is done proactively. Thus, TALL may be implemented not only with the aim to substitute for a teacher but, more importantly, to leverage one's own learning outside the classroom.

In sum, the main advantages of TELL boil down to (1) leveraging personal management of knowledge acquisition (personal knowledge management), (2) supporting self-initiated learning and the organisation of this process with the aid of others (self-directed learning), (3) fostering learner self-reliance (learner autonomy), and (4) developing self-reflected motivation leading to proactive learning (self-regulation). The evaluation of TELL related websites and apps has been offered by some scholars, for example, Liu et al. (2015) have analysed four of them, which they dubbed social network sites for language learning (SNSLL), and Yu et al. (2010) reviewed course management systems (CMSs) used for language learning.

\section{Theoretical underpinnings}

CALL is traditionally viewed as a subfield of Second Language Acquisition (SLA) theory; in particular, the interactionist approach (Chapelle, 1996, p. 142; Chapelle, 2005). There are voices (Egber et al., 2007, pp. 3-4) that a separate

\footnotetext{
${ }^{3}$ Whilst Knowles (1975, p. 18) sees some overlap of the term self-directed learning with inter alia autonomous learning, he stresses the fact that self-directed learning occurs in the milieu of other people (helpers), e.g., teachers, peers, mentors, tutors, rather than in isolation, as suggested by autonomy.

4 Benson (2001, p. 47) defines learner autonomy as "the capacity to take control over one's own learning".
} 
theoretical underpinning of CALL is not necessary, as "a clear theory of SLA and its implications" for the language learning environment plays this role (Egber et al., 2007, p. 4). This opinion stems from the fact that technology is integrated with numerous fields of investigation, and conceptually CALL draws on these varying perspectives (Egber et al., 2007, p. 4). Its presence in the field of language learning/teaching is increasingly "seamless" and invisible, which Bax (2011) dubbed normalisation. CALL may be embedded in a variety of existing SLA theories representing a number of theoretical perspectives, be that cognitive (i.e., following Chomsky's scholarship), psycholinguistic (including interactionist theory), human learning, or rooted in the social context (such as sociocultural theory) (Chapelle, 2009).

From a pedagogical/psychological perspective, CALL bears close affinities with Piagetian constructivism (Piaget and Inhelder, 1967[1948]), Vygotskian sociocultural theory (social-constructivism, Vygotsky, 1978), and Papert's constructionism (1980). Whilst constructivism assumes that in the spate of development, knowledge of the world is constructed by an individual as a result of a cognitive effort relying on internalisation of experiences (two processes termed assimilation and accommodation), social constructivism assigns knowledge acquisition to the social milieu that functions as a mediation between the existing knowledge and the new information. It is the interaction between the individual and the milieu that plays the key role in the sociocultural theory, where it is seen as the driving force for development (of higher mental activities), an aspect which constructivism overlooks. On the other hand, the capacities of (knowledge) constructor to extract abstract rules from empirical experiences, reinforced by an educator, who creates a motivating learning environment that supports self-learning, are crucial in constructivism. Strong affinities with constructivism may be seen in learner autonomy, self-directed and self-regulated learning which constitute the rudiments of CALL. The idea of collaborative learning shining through crowdsourcing ideas applied to education, in particular to language learning, is in turn supported by the pillars of the sociocultural theory of learning.

These two theories of development are, in a way, welded by the third one, which is a theory of learning and teaching put forward by Papert (1980). Constructionism reveals some affinities with Piaget in the sense that in both theories, knowledge is built by an individual as structures, yet unlike Piaget, the process does not rely on internalisation of personal experiences of the world but on their externalisation, i.e., on propositional self-expression, which is an empirical experience rather than a purely mental operation, 
and which is a shared creative activity (Papert, 1990, p. 3; Ackermann, 2001; Kafai, 2006). Learning is thus grounded in specific situations (context) that require other people to interact with; hence it endorses situated learning, and, in this aspect, Papert shares the assumptions voiced by Vygotsky. Importantly, constructionism stresses that learning is most effective when one is involved in the active construction of a product (learning by doing). In constructionism, "shared external constructions and social relations are key to individual development" (Shaw, 1996, p. 179), a thesis in which CALL in general, and SNSs (see below) in particular, perfectly incribe. What makes constructionism especially suitable for CALL is the fact that Papert contextualises his ideas in technology. He sees technological support as an effective environment for learning (like the creation of the Logo programming language used to teach mathematics to children), which allows one to immerse in the target knowledge and actively participate in its construction through performing tasks and manipulating physical objects (Papert, 1980). Of the three approaches, recently CALL is most often embedded in the socio-constructivist theory put forward by Vygotsky (e.g., Warschauer et al., 1996; Liu et al., 2015; Rahimi and Fathi, 2021; Bączkowska, in press), less frequently with Piagetian constructivism (e.g., Duffy and Cunningham, 1996).

\section{Research aim}

In what follows, some OLL forms will receive further attention, in particular web platforms for language learning, that will be dubbed here PALLs, and will include mobile applications for language learning (MALL) that are mobile versions of the PALLs in question, if the mobile versions are available. The aim of this paper is thus to present a succinct survey of currently available, most popular web-based and mostly cross-platform tools (website and mobile) that can be used to learn (or teach) a foreign language. The methodology of data collection will be presented in a subsequent section, which will be followed by an analysis of select OLL tools. Before that, however, the acronym PALL will be elucidated.

\section{Web platforms and apps for language learning (CMSs, LMSs, PALLs)}

Technically, the platforms described in what follows illustrate, in fact, varying types of tools, from the more advanced systems like CMSs (course management 
systems) or LMSs (learning management systems ${ }^{5}$ ) to simple, static websites or basic applications. A minority of scholars insist on the differences between CMSs and LMSs and ascertain that these are technologies that are certainly not equivalent as they "were developed for very different reasons even if they share certain functionalities" (Watson and Watson, 2007). Very often, however, in CALL literature, the acronym CMS is a term used interchangeably with LMS (e.g., by Stansfield and Conolly, 2009, p. 31; Peterson, 2009; Piña, 2010, p. 2; Tsai and Talley, 2014).

A CMS is described as a software package available online that facilitates "all aspects of course preparation, delivery and interaction" (Collins and Moonen, 2001, p. 78). Similarly, the term LMS is defined as software that allows monitoring learners' participation, tracking their progress, creating reports, archiving didactic materials, registering learners' evaluation results, embedding full-fledged language courses, etc. (Piña, 2010). In other words, an LMS is an e-learning system (also termed e-learning software, see Mahlow, 2010, pp. 58-59) for instructional content creation and display (generating course content), which uses synchronous (chat, whiteboard) and/or asynchronous (announcements, messages, discussion boards, file sharing, learners web pages) communication, and which implements assessment (testing tools and achievement tracking, grade books, logging time and duration), and administration tools (registration, customising the interface, granting permissions, moving content, etc.) (Dabbagh and Bannan-Ritland, 2005). Popular LMSs comprise Moodle, Blackboard, WebCT, eCollege, Desire2Learn, Angel, Sakai (Piña, 2010; Tsai and Talley, 2014), ILIAS, OLAT (Mahlow, 2010), Claroline and Dokeos (Ninoriya et al., 2011).

Incidentally, CMSs is also an acronym traditionally used in information and communication technology (ICT) where it stands for the content management system and is associated with storing and displaying content on a website and granting access to certain types of documents depending on permission level (blogs, for example, are created using CMSs) (see Ninoriya et al., 2011 for a comparison of CMSs used in ICT with LMSs). CMS used in ICT

${ }^{5}$ They are also dubbed LCMSs (learning content management systems). The two terms are often used interchangeably; however, some scholars (Oakes, 2002 in Watson and Watson, 2007; Ninoriya et al., 2011) maintain that there is a clear difference between them. According to Oakes, LMS focuses on the learner and learning organization, while LCMS is content-oriented. Thus, LMS refers to managing learners and the didactic process, by centralizing and automating administration as well as assembling, deploying and rapidly delivering personalized content (Ninoriya et al., 2011, pp. 645-646), while LCMS is software used to make, archive and distribute personalized e-learning content (Oakes, 2002, pp. 73-74). 
(CMS/ICT) functions more as a repository of content. Popular CMSs/ICT are WordPress, Joomla! and Drupal. It must be remembered that CMS/ICT (i.e., content-related) is a different concept from the term CMS used in CALL (i.e., course-related). CMSs/ICT, however, may be integrated with LMSs (Piotrowski, 2009, p. 3; Ninoriya et al., 2011). To make things more confusing, Yu et al. (2010) also deploy the acronym CMS to mean either what they dub computer management systems or course management systems, without defining the difference.

As already mentioned, along with CMSs/LMSs, simple websites and apps which allow creating one's own materials by teachers, checking select features by learners (e.g., how to pronounce words, spelling checkers, test generators), or learning only limited aspects of languages without the complex system of registering learners' activity on the platform (which require, e.g., creating databases) will also be included in the analysis. The acronym PALLs (Platforms and Apps for Language Learning) will be used here to span both the complex CMSs/LMSs as well as mobile apps ${ }^{6}$ or simple websites, which do not use or use only partially, complex managing systems. Put differently, language learning software located on websites and/or dedicated for mobiles will be dubbed PALLs, regardless of the degree of technical complexity.

Such a conceptualisation of e-learning tools results from three sources. Firstly, it has been inspired by the definition of an e-learning platform offered by Piotrowski (2009, p. 37), who prefers to use the term platform rather than CMS, LMS, LCMS, and the like in order to avoid focusing on the management features and to stress educational aspects. Thus, an e-learning platform is presented in Piotrowski (2010, p. 20) as a "software that provides the technical infrastructure on which e-learning activities can take place". A very broad understanding of e-learning, also adopted here, following Piotrowski (2009, p. 35), views it as "a general term describing all kinds of computer-mediated and computer-supported learning and teaching". Thus, the availability of educational content on websites/apps is emphasised over the technical solutions implemented to them.

Secondly, since the managing function is a matter of degree rather than a binary option (Piotrowski, 2010, p. 26), I did not want to enter into purely

\footnotetext{
${ }^{6}$ The difference between a computer program and an application (app) consists in the fact that the former is system-oriented, and the latter is user-oriented. Thus, a program is designed to allow a computer to execute specific tasks, and it often requires a PC installation, whereas an app is designed to answer the needs of an end user, it is usually a self-contained program or a part of a larger one with user-friendly interface. Importantly, while all apps are programs, not all programs are apps.
} 
technical discussions regarding how, and whether to a sufficient degree a software/app has enacted management functions, e.g., by adhering to the four features of LMSs identified by Dabbagh and Bannan-Ritland described above. Thus, a platform that meets the requirement of storing and creating content but has no communication tools or no assessment and administration functionalities could not be called LMS but could still be classified as a website platform used for language learning, thus an example of PALL.

Finally, of the three features typical of LMSs that Piotrowski (2009, p. 3) distinguishes - content management, communication facilities and functionality for assessment - only the third one (assessment) is specific to e-learning, in line with his reasoning. This means that a website/app which has, say, no chat function or no content management feature may still be classified as a form of e-learning. As a result of these definitional ambiguities and gradability of technical aspects, the more general term PALL will be deployed in what follows spanning barebone websites (with a simple app embedded), websites with implemented management systems, and mobile apps, mostly accompanying either of them.

\section{Criteria of analysis}

The criteria according to which the data were analysed comprise several types of information. Firstly, the four classical language skills, vocabulary knowledge and grammar rules were checked; in particular, which of these elements constituted the main focus of each PALL. Receptive skills and the knowledge of grammar and vocabulary can be successfully improved with the aid of CALL (García Botero et al., 2019, 2021; Loewen et al., 2020, p. 2012 and references therein). Within the productive skills, speaking is probably the least practised skill and thus least successful (Heift and Vyatkina, 2017; Lin and Warschauer, 2015, p. 394).

The learning levels available in the PALLs were also analysed, as well as the type of expected learning outcomes in line with B. Bloom et al.'s (1956) taxonomy and its revised version (Anderson et al., 2001). In connection with these, the level of language structure was noted, and this could be at any, or several, of the following planes: morphological, lexical, syntactical (grammatical) and discourse/text.

A revised version (Anderson et al., 2001) of Bloom et al.'s (1956) taxonomy consists of six major categories of description regarding learning outcomes: remembering (knowledge), understanding (comprehension), 
application (applying), analysis, evaluation, and creation (synthesis). Remembering is based on recalling facts and concepts by providing definitions, listing them, repeating, etc. Understanding consists in explaining facts and concepts which are verifiable by providing classifications, descriptions, explanations, translations, as well as by selecting elements, identifying them and locating them. Applying relies on using known information (words, structures) in new contexts and thus implementing new ideas, interpreting and solving problems, i.e., applying a known procedure to an unfamiliar task. A less demanding form of 'applying' requires using a known procedure to a familiar task, which is dubbed executing (Anderson et al., 2001). Most PALLs are amenable to executing rather than implementing. By making connections among ideas, a learner analyses them, that is, finds similarities and contrasts, matches ideas, organises them and finds relations among them. The next step in the hierarchy is an evaluation that involves higher-order mental operations such as judging, expressing critique, weighing arguments, arguing and defending. The highest level, requiring most mental engagement and effort, is creating, which means producing new work that is original and authorial. Thus, such measures as designing, constructing, developing something new or formulating new ideas exemplify the creative stage. The criteria used here engulfed both factual and abstract concepts. This is contrary to a cline of knowledge dimensions proposed by Anderson et al. (2001, p. 5) as a modification of Bloom et al.'s model, wherein 'factual' and 'abstract' were distinguished as distinct criteria for learning outcomes.

Following Widdowson $(2004$, p. 8, 16), discourse is understood here a stretch of words arranged in sequential order in speech, while by text, we mean stretches of written words which make a sentence, paragraph, etc. By a stretch of words, it is understood, following Stubbs (1983, p. 1), Jaworski and Coupland (1999, p. 1), van Dijk (1997, p. 1), and Schiffrin et al. (2003, p. 1), a sequence of words longer than a sentence, ,anything "beyond a sentence”" or "larger linguistic units". This distinction, into text and discourse, was adopted here for practical reasons, despite the fact that other scholars see this division as unnecessary (e.g., van Dijk, 1997, p. 3; Stubbs, 1983, p. 1; Fairclough, 1992, p. 28).

Another criterion considered in the survey was the availability of TALL tools, that is, whether they are free or subscription-based. The latter typically follows a free of charge demonstration version, which is usually a two-weeklong free trial. Cases wherein free access was only to the first lesson of all courses, as it is in the case of Babbel+, were not classified as free. There is yet another model of PALLs known as the freemium option, which consists 
in offering a product free of charge without limited time but with limited features, that is, with advanced functions available only in a premium option, which is based on a pricing offer.

Crowdsourcing is another criterion used in the analysis. It is a hazy term, which has over 40 definitions (Estellés and González, 2012). Initially proposed by Jeff Howe $(2006)^{7}$, the concept assumes collaborative work (learning) initiated through an open call (Brabham, 2017). In the classical definition, volunteers work on a common goal by contributing their work based on the varying competencies they have, to achieve a final product defined by the project initiator. In crowdsourcing applied to education, termed Crowdsourcing for Education or CfE for short (Jiang et al., 2018; Bączkowska, in press), the project initiator is an educator or an educational institution, and through an open call, they propose support in learning or teaching. The forms of collaborative work may take varying forms to secure "accurate and diverse feedbacks" and "flexible and personalised support" (Jiang et al., 2018), and these can involve: creating teaching content (Resources), providing practical exercises (Activities), exchanging knowledge (Support), or providing assessment feedback (Evaluation). In the PALLs analysed here, the predominant forms of CfE are Evaluation and Support. For example, fellow learners correct written or oral assignments of other learners and explain some linguistic issues (as it is on the Busuu platform). Thus, learning becomes a social experience wherein the community of peer learners, who constitute the internal crowd (Jiang et al., 2018), support one another and create a Network Learning (Warschauer and Kern, 2000).

Incidentally, some of the PALLs under investigation here classified as crowdsourcing platforms could also be classified as examples of social network sites (SNSs), whose main features comprise the possibility of creating one's own profile (public or semi-public) and articulating multiple links to other users of an SNS (Georgalou, 2020, p. 41, 61; boyd and Ellison, 2007), seeing and traversing the links of other users (boyd and Ellison, 2007) as well as "collaborat[ing] to share content" and to "form online communities" (Dufy, 2011). Another element added by some scholars is that SNSs reflect social connections and communities of practice already existing offline, i.e., prior to the creation of SNS, and that SNSs are only to maintain contact or to extend it to the virtual world (boyd and Ellison, 2007; Dufy, 2011; Yus, 2011, p. 115; Eisenlauer, 2017, p. 226). This requirement is not necessary for

7 First concepts of what was later termed crowdsourcing by Howe can be traced back, however, to the book Wisdom of the Crowds by J. Surowiecki (2004). 
the classification of a PALL as a crowdsourcing form of language learning. Following the definition proposed by Dufy, examples of SNSs in the PALLs analysed in this paper comprise inter alia Busuu, Babbel+, Italki and LingQ.

Site languages and supported languages have also been noted in the survey. Whilst the former term (also known as display languages) refers to the language through which one learns another (new) language, i.e., the language of instruction, the latter defines the target language one wishes to master. The necessary requirement that had to be met to include a platform/app to be analysed in the research was using English as one of the site languages.

Typology of exercises involves the type of interaction between the learner and the technological device used for learning. By device I mean one of the two options: website-based software or a mobile app often being an optional version of the website-based one. The app had to meet the criterion of installation on devices running the Android operating system (most of the apps could also run on iOS).

Finally, language levels offered by the PALLs were noted. The levels provided by the majority of PALLs were not specifically defined; rarely were they described in terms of CEFR (Busuu issues McGraw-Hill certificates commensurate with CEFR); thus, they should be treated as loose approximations of what is referred to as "intermediate" or "advanced" by the general public.

\section{Data collection methodology}

The selection of web-based platforms for language learning (PALLs) followed a three-step procedure. Firstly, an incognito Google search was conducted on a single PC using the same IP on the $5^{\text {th }}$ of July 2021. The main criterion used for PALLs selection was their popularity measured by their display order in the Google search engine. The results can differ in the case of other search engines. The choice of the Google search engine was dictated by the fact that of the largest search engines (Google, MS Bing, Yahoo!, Baidu, Yandex), the dominant search engine in the world is unquestionably Google, which takes $92.26 \%$ of the market share, followed by Bing $(2.83 \%-12.31 \%)$, Yahoo! (1\%), Baidu (0.68\%-11.26\%), and Yandex (0.5\%-1.16\%). [1].

The first ten platforms found as a result of the Google search were selected for further analysis. The top ten platforms displayed in the Google search included: Italki, FluentU, Duolingo, Busuu, Lingolex, Babbel, Mango languages, Memrise, LingQ, Worddio. Apart from these generally known websites, it was difficult to retrieve other websites that are also popular among 
language learners. Most hits returned by the Google search constitute links to a number of Internet pages that only describe PALLs or to advertising websites rather than to the PALLs themselves. The ten Google-based PALLs selected for the present analysis were, in fact, found across as many as the first 80 hits displayed by Google; hence, another step of data retrieval had to be employed. More websites were added to the list based on listings of the top ten websites/apps for language learning (and titled in this way). These websites used their own criteria (which were not disclosed) to select the most popular or the best in their opinion software programs. The top ten platforms in 2021 proposed most often mentioned by websites reviewing e-tools used in language learning and teaching were somewhat different from those retrieved from the Google search engine, and they encompass the following: Rosetta Stone, Duolingo, Busuu, Babbel+, Memrise, AnkiApp, Yabla, LingQ Mango Languages, Italki. Finally, to encompass still more websites, other widely known PALLs were considered, for example, websites maintained by big media operators, such as Deutsche Welle Deutsche Lernen, BBC or Voice of America, as well as platforms well known to the teachers' milieu, such as Kahoot, Quizlet, gap-filling generator, or which the author knows from experience and found useful and worth popularising, for example, Skell, Learn Click, LARA or ClipFlair, even though they did not display within the first 80 links provided by the Google search.

In addition to that, two exclusion criteria were applied. Namely, only those platforms were investigated which used English as a display language, or where English was one of the site languages, i.e., it was used as a language of instruction (with the exclusion of the websites for sheer flashcard creation, where the language of instruction was tantamount to the source language selected by teachers/learners themselves). Secondly, as the study was conducted within the Cost Action project devoted to a limited pool of languages, only those software programs were taken into account, which contained the native languages spoken by the project members, as only these languages were investigated within the measures of the project. This does not mean that software that comprises other languages has been ignored, for if it also taught the project members' languages, it was taken into account (thus such languages like Indonesian, Japanese, Korean, Basque, etc. have also been included in the analysis even though representatives of the relevant countries were not members of the project). Only websites/apps which deal with other languages with the exclusion of those spoken by the project members were disregarded (for example, a very good website for beginners in Norwegian (Nyheter i bilder; 
nyb.no) was ignored in the study as it deals with Norwegian only, which was not represented by any members).

As a result of the threefold procedure of PALLs selection, the following 30 platforms/apps were used for the present analysis:

AnkiApp (https://www.ankiapp.com),

BBC for learning (https://www.bbc.co.uk/learningenglish),

Babbel+ (babbel.com),

Beelinguapp (https://www.beelinguapp.com),

Busuu (busuu.com),

Clip Flair (http://clipflair.net),

Deutsche Welle Deutsch Lernen (https://learngerman.dw.com),

Duolingo (duolingo.com),

Fiszkoteka (https://fiszkoteka.pl),

Flashcard Generator (https://flashcard.online),

FluentU (fluentu.com),

gap filling generator (johnsels.com),

How to pronounce (https://www.howtopronounce.com),

Italki (https://www.italki.com),

Kahoot (https://kahoot.com),

LARA (https://lara-portal.unige.ch/view/index.php),

Language Crush (https://languagetools.io/teachers),

Learn Click (learnclick.com),

Lingolex (lingolex.com),

Lingvist (lingvist.com),

LingQ (https://www.lingq.com),

Mango Languages (https://mangolanguages.com),

Memrise (https://memrise.com),

Quizlet (quizlet.com),

Rhino Spike (https://rhinospike.com),

Rosetta Stone (https://www.rosettastone.com),

SKELL (https://www.sketchengine.eu/skell),

Voice of America (https://learningenglish.voanews.com),

Worddio (https://worddio.com),

Yabla (https://www.yabla.com). 


\section{Research results}

\subsection{Language skills}

Four classical language skills were considered in the analysis: listening and reading as receptive skills as well as speaking and writing on the production end. All skills included both extended passages (e.g., reading fragments from newspapers, writing one's own paragraph-long or longer passages) as well as micro-level units (e.g., self-audio recording of single words or short sentences, spelling exercises involving writing single words, etc.). The proportion of each skill across the PALLs in question is illustrated by Fig. 1. It shows that most PALLs hone receptive skills, i.e., listening and reading. Productive skills are also practised, but they constitute one-third of the activities offered by the PALLs relative to receptive skills. This result is not surprising as, without the human teacher, it is quite an arduous task to improve one's competencies in speaking or writing. The PALLs that allow one to improve all four skills are the following: Babbel+, Rosetta Stone, Duolingo, ClipFlair and Busuu. The last two are in addition crowdsourcing tools.

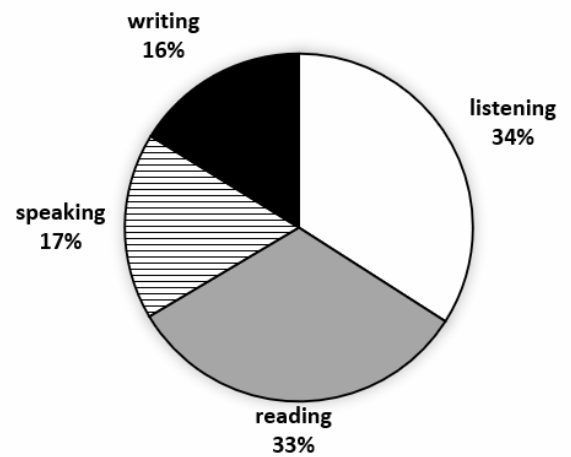

Fig. 1. Language skills practice in PALLs

\subsection{Grammar and vocabulary knowledge}

The most common input practised on all PALLs and apps is vocabulary, with the predominant technique of using flashcards. Twenty-four out of thirty platforms verified learners' knowledge of lexis, and eighteen of them checked their competence in grammar rules. Activities supporting learning new words can be found in Ankiapp, BBC for learning, Babbel+, Busuu, Deutsche Welle Deutsch Lernen, Duolingo, Fiszkoteka, FluentU, gap-filling generator, Italki, Kahoot, LARA, Language Crush, LearnClick, Lingolex, Lingvist, LingQ, Mango 
Languages, Memrise, Quizlet, Rosetta Stone, SkeLL, Voice of America, Worddio, Yabla. Grammar is supported in turn by the following PALLs: BBC for Learning, Babbel+, Busuu, Deutsche Welle Deutsch Lernen, Duolingo, Fiszkoteka.

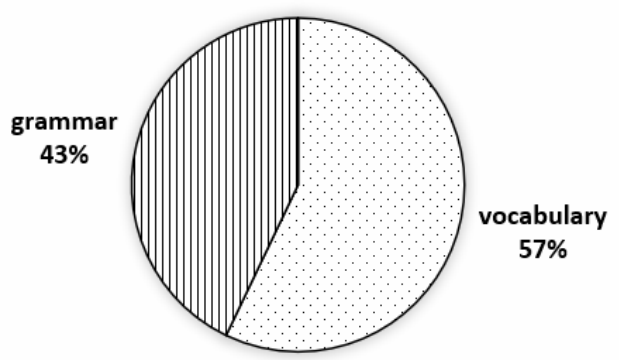

Fig. 2. Grammar versus vocabulary practice present in PALLs

\subsection{Language learning level}

The language level was labelled as "any", if the level depends on the input data resulting from crowdsourcing or PALL users, or "beginning", "intermediated", "advanced". Sixteen PALLs have been tagged as "any", nine of them span all three levels, three offer materials from beginner to intermediate (Duolingo, Lingolex, Worddio) and two from intermediate to advanced (LARA, LingQ). From the statistical information, it transpires that a vast majority of PALLs can be used at least up to the intermediate level and over $80 \%$ for the traditional three levels.

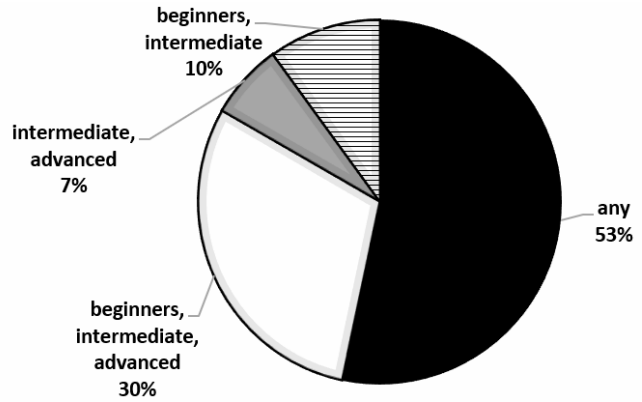

Fig. 3. Declared language levels

\subsection{Language structure level}

The majority of PALLs offer materials on the lexical level (five platforms), lexical and discourse/text level (eighteen platforms), viz. using lexis in context, or grammatical level along with lexical and discourse. Lexical input can be practised through flashcards (Ankiapp, Flashcard generator, Fiszkoteka, 
Lingvist) and a platform providing pronunciation recordings (How to Pronounce). Lexis together with text/discourse is emphasised by: BBC learning, Beelinguapp, Clip Flair, Deutsche Welle, FluentU, Italki, Language Crush, LARA, Lingolex, LingQ Mango Languages, Memrise, Rhino Spike, Rosetta Stone, SKELL, Voice of America, Worddio and Yabla. These websites propose activities that focus on deploying both single words and using language in longer oral or written expression. Eight platforms focus on lexis and texts along with exercises devoted to grammar: Babbel+, Bussu, Duolingo, gap-filling generator, Kahoot, Learn Click, FluentU, Quizlet. Overall, most platforms/apps provide materials to practise vocabulary and words in context (text, discourse).

Incidentally, for some PALLs, the language structure level input depends on the learners/teachers; for example, Kahoot allows one to practice text/discourse if some text is uploaded to the system or a video film is embedded, whereas Quizlet is mainly used for learning/teaching single words or phrases, but it can be easily used at the level of grammar. Moreover, the quality of vocabulary knowledge offered by these platforms is not the same. Most platforms afford achieving passive knowledge of words, usually enacted by matching or drag-and-drop exercises, as in Duolingo, or just reading examples, as in SKELL, rather than an active one, as in, e.g., Busuu, where words need to be used in a more creative manner. Being a much-simplified version of the Sketch Engine (www.sketchengine.eu), SKELL allows one to search through language corpora, retrieve synonyms and create concordances. SKELL is prepared for didactic purposes, and its main asset for language learning/teaching is showing a number of examples (retrieved from large corpora) in context, thus supporting passive knowledge of words and/or grammatical structures.

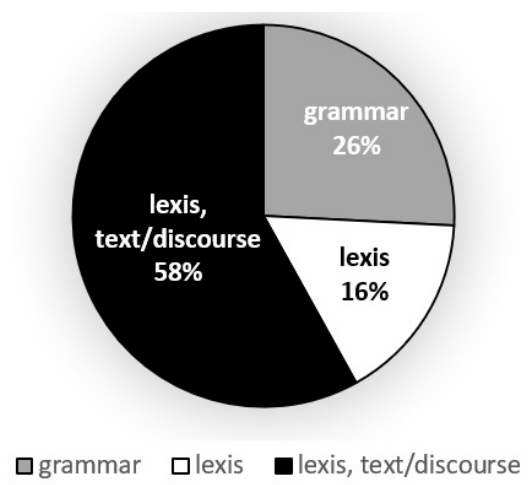

Fig. 4. The levels of language at lexical, structure and text/discourse planes 
It must be remembered, however, that the level of difficulty varies, especially regarding the text level. For example, the exercises at the sentence level in Duolingo consist mainly in drag-and-drop technique and putting words in the correct order, and often the tasks do not require writing a stretch of words on one's own, while in other PALLs, such as Busuu, one needs to generate a short paragraph on one's own, which is much more difficult (either in the form of a text or a short audio-recorded presentation). Some hints as to what to write or say can also be uncovered, though, e.g., in Busuu, which makes producing longer stretches of text or discourse a manageable rather than a daunting task. Learners thus get involved in practising a language at text/discourse level to a different degree. From this, it transpires that an important aspect of PALLs is the degree of involvement and creativity expected from the learner. This aspect of language learning can be described by Bloom et al.'s learning outcomes.

\subsection{Learning outcomes}

The lowest level of learner engagement in the learning process is dubbed understanding. Only one PALL has been identified as exemplifying this single outcome (Beelinguapp). A number of PALLs are illustrative of the two lowest outcomes, that of understanding (28 platforms) and remembering (28 platforms). Of the two subprocesses subsumed by applying (execution and implementing), implementing has been observed in the minority (ClipFlair, Italki), as they require less controlled practice and thus more creativity, that is, applying known procedures to unfamiliar tasks. The majority of PALLs, however, relied on carrying out (executing) known procedures in familiar tasks (such as filling in the blanks, choosing the right answer, etc.), which are, essentially, rather limited in scope and minimal in terms of cognitive engagement, and which aim at practising new words and structures or revising them. Altogether, applying occurs in seven PALLs. The cognitive process of analysing has been present in 16 PALLs, and it consists in presenting copious, short exercises wherein the aim is to discriminate relevant from irrelevant information in the context, to recognise the function of some elements in a context, as well as to determine viewpoints. Only seven platforms demanded creativity on the part of the learner. The degree of creative measures varies, from, for example, writing several sentences on a given topic (e.g., in Busuu), to writing the whole script for a film fragment (select scenes from feature or documentary films in the form of voice-over text or as subtitles, as in ClipFlair). The least common learning outcome turns out to be evaluation, 
which can be reached with the aid of three platforms (ClipFlair, Italki, Language Crush). Whist Italki is based on live lessons with native speakers, and thus expressing evaluative comments (judgements and critique) is possible mainly while practising speaking, ClipFlair and Language Crush permit written expression. ClipFlair allows learners to voice their opinions in the form of film dialogues, whereas Language Crush in short essay type of writing. Taken together, the distribution of learning outcomes across the platforms investigated here is shown in Fig. 5. Overall, the prevailing types of learning outcomes rely on rather uncreative and repetitive or passive actions on the part of the learner, which is hardly surprising, allowing for the fact that language apps/platforms are created mainly for beginners and intermediate students who learn without teachers' assistance (excluding Italki).

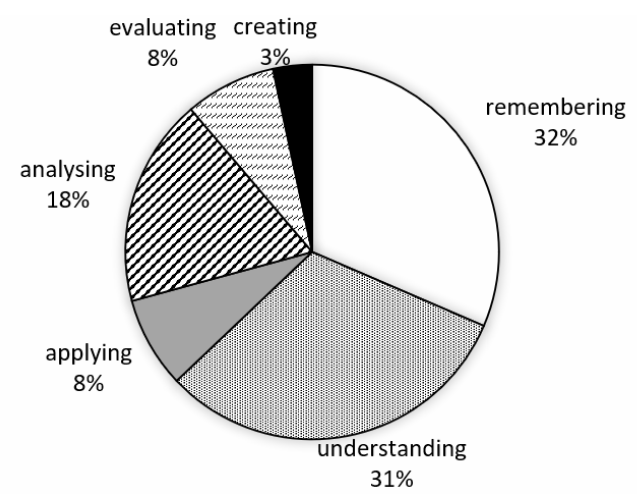

Fig. 5. Learning outcomes distribution

\subsection{Display languages and supported languages}

As mentioned above, all PALLs under investigation provide learners with English as the display language or with platforms where the choice of display language is of little or no importance, as it is in the case of flashcard creation (e.g., Fiszkoteka is a platform originally created for Polish learners yet the choice of the source language for flashcards depends entirely on the creator of flashcards, be that the teacher or learners themselves). Any language (subject to users' choices) could be used in the case of eight PALLs; other popular languages of instruction comprise German, French and Spanish. Occasionally, less popular languages are available, such as Belarusian (Worddio), Czech (SKELL), Estonian (SKELL, Lingvist), Basque (ClipFlair), Catalan (ClipFlair), Polish (Fiszkoteka), Turkish (Busuu, Babbel+), Swedish (Beelinguapp, Babbel+), Norwegian (Babbel+), Indonesian (Babbel+), Danish (Babbel+), Romanian (AnkiApp), Korean (FluentU), Japanese (FluentU, Lingvist, Worddio). 


\subsection{Types of exercises}

The most common teaching techniques comprise using (or creating own) flashcards. Very popular types of activities involve listening to podcasts/audio recordings and watching short video content. Reading passages (longer than one sentence) is typical of PALLs that revolve around the idea of learning through reading (e.g., LARA, LingQ), particularly through exposure to authentic texts (literature, newspapers), yet they are not widely explored. Within the PALLs examined, there are several full language courses, wherein the four language skills, vocabulary, grammar and pronunciation practice are built around a single theme and grammar problem, and the whole material is marshalled in didactic units (e.g., Rosetta Stone, Busuu), these, however, remain in the minority. Matching (lexical or grammatical elements) and single choice exercises are also relatively frequent. Disregarding full language courses, in other platforms/apps, the following types of activities are least popular: translation, self-recording, writing short passages, scrambled words in a sentence and concordances.

\subsection{Type of device and availability}

Of 30 PALLs analysed here, 25 are web platforms/desktop apps, two are only available as mobile apps (Beelinguapp, Worddio), and three are accessible solely through websites (ClipFlair, LARA, SKELL). Put differently, over $80 \%$ of all PALLs under investigation are offered in two modes: web-based and mobile. As for PALLs availability, more than half of the programs at hand are completely free; about $30 \%$ are based on a recurring subscription, while freemium options take up almost $20 \%$.

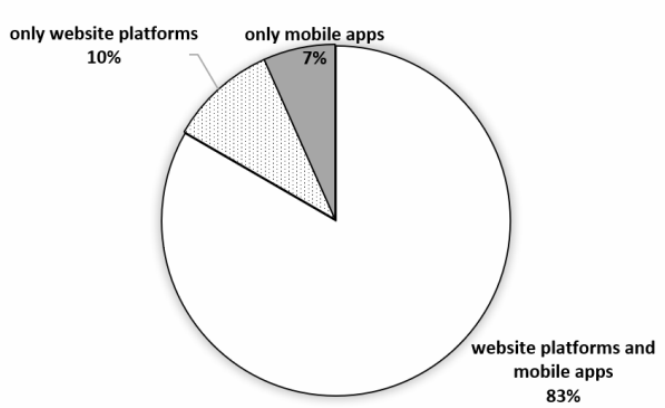

Fig. 6. Type of device used in PALLs

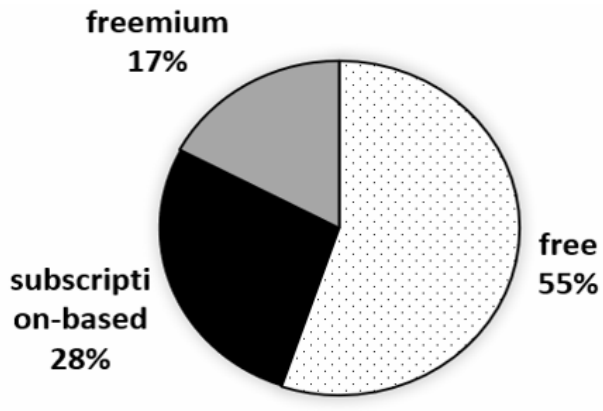

Fig. 7. Availability of PALLs 


\subsection{Crowdsourcing in education (CfE)}

Even though the CfE is not widely practised as yet, a growing tendency can be observed of adding crowdsourcing options to the existing PALLs; particularly, to those based on website platforms. The typical forms of CfE comprise either building a repository of crowd-based data (resources in Jiang et al.'s parlance), dubbed crowd-teaching or crowd-learning (Prester et al., 2019), or allowing other learners to correct assignments of others (evaluation and support), known as crowd-assessing (Prester et al., 2019). For example, on the Busuu platform, written tasks are revised by volunteers, that is, other learners subscribed to this platform, usually by native speakers of the assignment language. Learners' recordings, an optional oral assignment on Busuu, are also sent as requests to comment by others. The community is very supportive as the comments are typically mild and suggestive rather than mocking. Similar comment- and correction-based contributions (performance-based crowd assessment) are also possible in Duolingo (community forum), Language Crush ('write and correct' and 'community forum'), and LARA (community social media forum). Crowdsourcing measures, yet of a different type, are also present in, e.g., ClipFlair (where learners prepare video clips with their own voice-over passages or subtitles), LARA (crowdsourcers translate whole narrative passages, usually pieces of literature), Duolingo (whole course content is sourced from volunteers), Quizzlet and Kahoot (where tests and exercises are contributed by the crowd, occasionally activities based on built-in videos), AnkiApp and Fiszkoteka (flashcards are created), as well as How to Pronounce, and Rhinospike (native speakers record pronunciations upon request). Italki, on the other hand, instantiates crowdteaching, where peers volunteer to teach (as tutors) the languages of their choice (which are not only their native languages). Crowdsourcing may thus consist in creating whole repositories of exercises, pronunciation recordings, vocabulary, etc. (crowd-teaching, crowd-learning) or may play an ancillary role relative to core or coursebook materials (crowd-assessing).

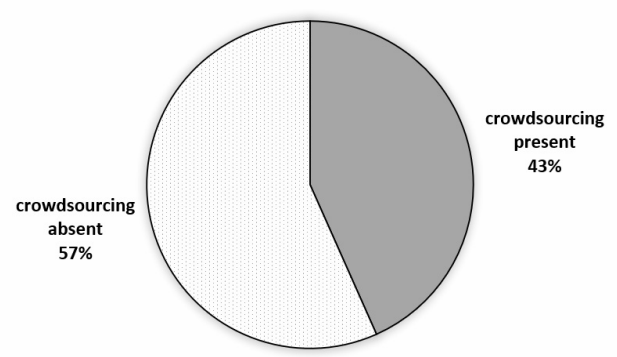

Fig. 8. Crowdsourcing in PALLs 


\section{Conclusions}

Of the four well-known language skills, listening and reading are the predominant language skills practised (they constitute about $60 \%$ of all skills). Considering learning outcomes, remembering and understanding constitute two-thirds of all learning outcome types, with $20 \%$ also taken by analysing. The platforms afford practising a language mainly at the text/discourse level (58\%), showing thus foreign vocabulary and grammar in a wider context, at the grammatical structure level (phrasal or sentential) $26 \%$ of the input material is presented, and $16 \%$ is at the word level. Twothirds of the courses are devoted to teaching vocabulary (some of them exclusively to lexis) and one third to grammar. Thus, language platforms are usually created for vocabulary learning and revision. The most popular types of activities are flashcards, short video films and listening passages, as well as matching and single choice exercises. Over $80 \%$ of PALLs declare that the material is prepared for all language levels (that is from beginners to advanced); however, it is not clear in most cases how accurately the terms 'beginners', 'intermediate' and 'advanced' tally with the acknowledged language level descriptions, such as, e.g., the Common European Framework of Reference for Languages. Crowdsourcing solutions are present in a number of platforms/apps but they still constitute less than half of the PALLs under investigation.

\section{Acknowledgement}

This research was financially supported by the EU project "enetCollect", COST ACTION CA16105, and it was conducted during my one-month scientific stay at Arni Magnusson Institute in Reykjavik, Iceland, in July 2021, where I was hosted by Dr Branislav Bédi. The financial support is greatly acknowledged.

\section{Internet sources}

[1] https:/www.reliablesoft.net/top-10-search-engines-in-the-world9/

\section{REFERENCES}

Ackermann, E. K. (2001). Piaget's constructivism, Papert's constructionism: What's the difference? Future of Learning Group Publication, 5(3), 438. http://learning.media.mit.edu/ content/publications/EA.Piaget\%20_\%20Papert.pdf, Accessed 19 April, 2021.

Ahmad, K., Corbett, G., Rogers, M. \& Sussex, R. (1985). Computers, language learning and language teaching. Cambridge: CUP. 
Allodi, A., Dokter, D. \& Kuipers, E. (2014). WELLS: Web-Enhanced Language Learning. In A. van Essen, S. Jager \& J. Nerbonne (Eds.), Language Teaching and Language Technology (pp. 123-135). London: Routledge.

Anderson, L. W., Krathwohl, D. R., Airasian, P. W., Cruikshank, K. A., Mayer, R. E., Pintrich, P. R., Raths, J. R., \& Wittrock, M. C. (Eds). (2001). A Taxonomy for Learning, Teaching, and Assessing: A Revision of Bloom's "Taxonomy of Educational Objectives". Abridged Edition. New York: Longman.

Bax, S. (2011). Normalisation Revisited: The Effective Use of Technology in Language Education. International Journal of Computer $\square$ Assisted Language Learning and Teaching, 1(2), 1-15.

Bax, S. (2003). CALL-past, present and future. System, 31, 13-28.

Bączkowska, A. (in press). Barngarla - język australijskich Aborygenów na crowdsourcingowej platformie edukacyjnej LARA.

Benson, P. (2001). Teaching and Researching Autonomy in Language Learning. London: Longman.

Blake, R. J. (2011). Current trends in online language learning. Annual Review of Applied Linguistics, 31, 19-35.

Blin, F. (2004). CALL and the development of learner autonomy: towards an activity-theoretical perspective. ReCALL, 16(2), 377-395.

Bloom, B. S., Engelhart, M. D., Furst, E. J., Hill, W. H., \& Krathwohl, D. R. (1956). Taxonomy of educational objectives: The classification of educational goals. Handbook I: Cognitive domain. New York: David McKay Company.

Boyd, D., \& Ellison N. (2007). Social Network Sites: Definition, history and scholarship. Journal of Computer-Mediated Communication, 13(1), 210-230.

Brabham, D. C. (2017). Crowdsourcing. MIT Press.

Chapelle, C. A. (1996). CALL - English as a second language. Annual Review of Applied Linguistics, 16, 139-157.

Chapelle, C. A. (2005). Interactionist SLA theory in CALL research. In J. J. Egbert, \& G. M. Petrie (Eds), CALL Research Perspectives (pp. 53-64). London: Routledge.

Chapelle, C. A. (2009). The relationship between Second Language Acquisition Theory and Computer-Assisted Language Learning. The Modern Language Journal, 93, 741-753.

Chapelle, C. A. (2019). Technology-mediated language learning. In J. W. Schwiter \& A. Benati (Eds.), The Cambridge Handbook of Language Learning (pp. 575-596). Cambridge: CUP.

Cigognini, M. E., Pettenati M.C., \& Edirisingha, P. (2011). Personal Knowledge Management skills in Web 2.0-based learning. In M. J. W. Lee \& C. McLoughlin (Eds.), Web 2.0-Based E-Learning: Applying Social Informatics for Tertiary Teaching (pp. 109-127). Hershey: IGI Global.

Collis, B., \& Moonen, J. (2001). Flexible Learning in a Digital World: Experiences and Expectations. London: Kogan Page.

Dabbagh, N., \& Bannan-Ritland, B. (2005). Online Learning: Concepts, Strategies, and Applications. Upper Saddle River, NJ: Pearson Prentice Hall.

Duffy, P. (2011). Facebook or Faceblock: Cautionary tales exploring the rise of social networking within tertiary education. In C. McLoughlin \& M. Lee (Eds.), Web 2.0-based E-learning: Applying social informatics for tertiary teaching (pp. 284-300). Hershey, PA: IGI Global.

Duffy, T. M., \& Cunningham, D. J. (1996). Constructivism: Implications for the design and delivery of instruction. In D. H. Jonassen (Ed.), Handbook of Research on Educational Communications and Technology (pp. 170-198). New York: Scholastic. 
Egbert, J., Hanson-Smith, E., \& Chao, C. (2007). Introduction: Foundations for teaching and learning. In J. Egbert, \& E. Hanson-Smith (Eds.), CALL Environments: Research, Practice and Critical Issues (pp. 1-14). Alexandria, VA.: TESOL.

Eisenlauer, V. (2017). Social Network Sites/Facebook. In C. R. Hoffmann, \& W. Bublitz (Eds.), Pragmatics of Social Media (pp. 225-242). Berlin/Boston: The Gruyter Mouton.

Estellés, E., \& González, F. (2012). Towards and Integrated Definition of Crowdsourcing. Journal of Information Science, 38(2), 189-200.

Fairclough, N. (1992). Introduction. In N. Fairclough (Ed.), Critical Language Awareness. London: Longman.

Frand, J., \& Hixon, C. (1999). Personal Knowledge Management: Who, What, Why, When, Where, How? Working Paper, UCLA Anderson School of Management. Retrieved from: http://www.anderson.ucla.edu/faculty/jason.frand/researcher/speeches/PKM.htm. DOA: 14.08.2008.

García Botero, G. A., Botero Restrepo, M. A., Zhu, C., \& Questier, F. (2021). Complementing inclass language learning with voluntary out-of-class MALL. Does training in selfregulation and scaffolding make a difference? Computer Assisted Language Learning, 34:8, 1013-1039, DOI: 10.1080/09588221.2019.1650780

García Botero, G. A., Questier, F., \& Chang Zhu (2019). Self-directed language learning in a mobile-assisted, out-of-class context: do students walk the talk? Computer Assisted Language Learning, 32(1-2), 71-97, DOI: 10.1080/09588221.2018.1485707

Garrison, D. R. (1997). Self-directed learning: Towards a comprehensive model. Adult Education Quarterly, 48(1), 18-33.

Garrison, D. R., \& Anderson, T. (2003). E-Learning in the 21st Century. London: Routledge.

Georgalou, M. (2010). 'Pathfinding' Discourses of Self and Social Network Sites. In R. Taiwo (Ed.), Handbook of Research on Discourse Behavior and Digital Communication: Language Structures and Social Interaction (pp. 39-65). Hershey: Information Science Reference. https://doi.org/10.4018/978-1-61520-773-2.ch003

Gitsaki, C., \& Taylor, R. P. (1999). Bridging the www into the ESL classroom. In K. Cameron (Ed.), CALL and the Learning Community (pp. 143-160). Exeter: Elm Bank.

Golonka, E. M., Bowles, A. R., Frank, V. M., Richardson, D. L., \& Freynik, S. (2014). Technologies for foreign language learning: A review of technology types and their effectiveness. Computer Assisted Language Learning, 27(1), 70-105.

Heift, T. (2005). Inspectable learner reports for Web-based language learning. ReCALL, 17(1), 32-46.

Heift, T., \& Vyatkina, N. (2017). Technologies for teaching and learning L2 grammar. In C. Chapelle, \& S. Sauro (Eds.), The Handbook of Technology and Second Language Teaching and Learning (pp. 555-569). London: Routledge.

Herring, S. C. (2001). Computer-Mediated Discourse. In D. Schiffrin, D. Tannen, \& E. H. E. Hamilton (Eds.), The Handbook of Discourse Analysis (pp. 612-634). London: Blackwell.

Holec, H. (1980). Learner training: Meeting needs in self-directed learning. In H. B. Altman, \& C. Vaughan James (Eds.), Foreign Language Learning: Meeting Individual Needs (pp. 30-45). Oxford: Pergamon.

Kafai, Y. B. (2006). Constructionism. In R. K. Sawyer (Ed.), The Cambridge Handbook of the Learning Sciences (pp. 35-46). Cambridge: CUP.

Knowles, M. (1975). Self-directed learning: A guide for learners and teachers. New York, NY: Association Press. 
Lai, C., \& Gu, M. (2011). Self-regulated out-of-class language learning with technology. Computer Assisted Language Learning, 24(4), 317-335.

Lai, C., Shum, M., \& Tian, Y. (2016). Enhancing learners' self-directed use of technology for language learning: the effectiveness of an online training platform. Computer Assisted Language Learning, 29(1), 40-60.

Lave, J., \& Wenger, E. (1991). Situated Learning: Legitimate Peripheral Participation. Cambridge: Cambridge University Press.

Levy, M. (1997). Computer-Assisted Language Learning: Contexts and Conceptualisation. Oxford: Clarendon Press.

Li, Y., Li, X., Su, Y., Peng, Y., \& Hu, H. (2020). Exploring the role of EFL learners' online selfregulation profiles in their social regulation of learning in wiki-supported collaborative reading activities. Journal of Computers in Education, 7, 575-595.

Liaw M.-I., \& K. English. (2017). Technologies for teaching and learning L2 reading. In C. A. Chapelle, \& S. Sauro (Eds.), The Handbook of Technology and Second Language Teaching and Learning (pp. 62-76). Oxford: Wiley Blackwell.

Lin, C. H., \& Warschauer, M. (2015). Online foreign language education: what are the proficiency outcomes? The Modern Language Journal, 99(2), 394-397.

Liu, M., K. Abe, M. W. Cao, S. Liu, D. U. Ok, J. Park, C. Parrish, \& V. G. Sardegna. (2015). An analysis of social network websites for language learning: Implications for teaching and learning English as a Second Language. CALICO, 31(1), 113-152.

Loewen, S., Isbell, D. R., \& Sporn, Z. (2020). The effectiveness of app-based language instruction for developing receptive linguistic knowledge and oral communicative ability. Foreign Language Annals, 53, 209-233.

Mahlow, C. (2010). Choosing the appropriate e-learning system for a university. In Y. Kats (Ed.), Learning Management System Technologies and Software Solutions for Online Teaching: Tools and APALLications (pp. 57-80). Hershey, PA: IGI Global.

Ninoriya, S., Chawan, P. M., \& Meshram, B. B. (2011). CMS, LMS and LCMS for e-learning. IJCSI International Journal of Computer Science, 8(2), 466-647.

Oakes, K. (2002). E-learning: LCMS, LMS - They're not just acronyms but powerful systems for learning. Training and Development, 56(3), 73-75.

Papert, S. (1980). Mindstorms. Children, Computers and Powerful Ideas. New York: Basic books.

Peterson, M. (2009). Learner interaction in synchronous CMC: A sociocultural perspective. Computer Assisted Language Learning, 22(4), 303-321.

Piaget, J., \& Inhelder, B. (1967[1948]). The Child's Concept of Space. New York: Norton Library.

Piña, A. A. (2010). An overview of Learning Management Systems. In Y. Kats (Ed.), Learning Management System Technologies and Software Solutions for Online Teaching: Tools and Applications (pp. 1-19). Hershey, PA: IGI Global.

Piotrowski, M. (2009). Document-Oriented E-Learning Components. [PhD Thesis, Otto-von Guericke-University Magdeburg, Germany]. https://files.eric.ed.gov/fulltext/ED533734.pdf. Access: 5.08.2021.

Piotrowski, M. (2010). What is an e-learning platform? In Y. Kats (Ed.), Learning Management System Technologies and Software Solutions for Online Teaching: Tools and Applications (pp. 20-36). Hershey, PA: IGI Global.

Placencia, M. E., \& Eslami, Z. R. (2000). Complimenting behavior and (self-)praise across social media. New contexts and new insights. Amsterdam: John Benjamins.

Rahimi, M., \& Fathi, J. (2021). Exploring the impact of wiki-mediated collaborative writing on EFL students' writing performance, writing self-regulation, and writing self-efficacy: 
a mixed methods study. Available at: https:/www.tandfonline.com/doi/abs/10.1080/ 09588221.2021.1888753?journalCode=ncal20. DOA: 23.07.2021

Reinders, H., \& Hubbard, P. (2013). CALL and learner autonomy: Affordances and constraints. In M. Thomas, H. Reinders, \& M. Warschauer (Eds.), Contemporary Computer-Assisted Language Learning (pp. 359-376). London: Bloomsbury.

Ruipérez, G. (2002). Web Assisted Language Learning (WALL) and Learning Management Systems (LMS) in virtual centres for foreign languages. International Journal of English Studies, 2(1), 81-95.

Schiffrin, D., Tannen, D., \& Hamilton, H. E. (Eds.). (2003). The Handbook of Discourse Analysis. Malden, MA.

Schulze, M., \& Heift, T. (2013). Intelligent CALL. In M. Thomas, H. Reinders, \& M. Warschauer (Eds.), Contemporary Computer-Assisted Language Learning (pp. 249-266). London: Bloomsbury.

Shaw, A. (1996). Social Constructionism and the inner city: Designing environments for social development and urban renewal. In Y. Kafai, \& M. Resnick (Eds.), Constructionism in Practice: Designing, Thinking, and Learning in a Digital World (pp. 175-206). Mahwah, New Jersey: Lawrence Erlbaum.

Stansfield, M., \& Conolly, T. (2009). Institutional Transformation through Best Practices in Virtual Campus Development: Advancing E-Learning Policies. Hershey, PA: IGI Global.

Stockwell, G. (2012a). Mobile-Assisted Language Learning. In M. Thomas, H. Reinders, \& M. Warschauer (Eds.), Contemporary Computer-Assisted Language Learning (pp. 201-216). London: Bloomsbury.

Stockwell, G. (2012b). Comptuter Assited Language Learning. Cambridge: CUP.

Stubbs, M. W. (1983). Discourse Analysis. Oxford: Blackwell.

Su, Y., Li, Y., Liang, J-C., \& Tsai, C. C. (2018). Moving literature circles into wiki-based environment: the role of online self-regulation in EFL learners' attitude toward collaborative learning. Computer Assisted Language Learning, 32 (5-6), 556-586.

Surowiecki, J. (2004). The Wisdom of Crowds. Random House.

Tsai, Y. R., \& Talley, P. C. (2014). The effect of a course management system (CMS)-supported strategy instruction on EFL reading comprehension and strategy use. Computer Assisted Language Learning, 27(5), 422-438.

Van Dijk, T. (1997). The Study of Discourse. In T. van Dijk (Ed.), Discourse as Structure and Process (pp. 1-34). London: SAGE.

Vinther, J. (2012). Cognitive skills through CALL-enhanced teacher training. In F. Zhang (Ed.), Computer-Enhanced and Mobile-Assisted Language Learning: Emerging Issues and Trends (pp. 158-187). Hershey, PA: IGI Global.

Vovides, Y., Sanchez-Alonzo, S., Mitropoulou, V., \& Nickmans, G. (2007). The use of e-learning course management systems to support learning strategies and to improve self-regulated learning. Educational Research Review, 2, 64-74.

Vygotsky, L. (1978). Mind in Society: The development of higher psychological processes. Cambridge, MA.: Harvard University Press.

Warschauer, M. (1996). Computer-assisted language learning: an introduction. In S. Fotos (Ed.), Multimedia language teaching (pp. 3-20). Tokyo: Logos.

Warschauer, M., \& Kern, R. (2000). Network-based language teaching: concepts and practice. Cambridge: CUP. 
Warschauer, M., Turbee, L., \& Roberts, B. (1996). Computer learning networks and student empowerment. System, 24(1), 1-14.

Watson, W. R., \& Watson, S. L. (2007). An Argument for Clarity: What are Learning Management Systems, What are They Not, and What Should They Become? TechTrends, 51(2), 28-34.

Widdowson, H. G. (2004). Text, context, pretext: Critical issues in discourse analysis. London: Blackwell.

Yu, W-K., Sun, Y-C., \& Chang, Y-J. (2010). When technology speaks language: an evaluation of course management systems used in a language learning context. ReCALL, 22(3), 332-355.

Yus, F. (2011). Cyberpragmatics: Internet-Mediated Communication in Context. Amsterdam: John Benjamins.

Zheng, C., Liang, J. C. Li, M., \& Tsai, C. C. (2018). The relationship between English language learners' motivation and online self-regulation: A structural equation modelling approach. System, 76, 144-157. 
